\title{
Anti-wrinkle effect of berberine by inhibition of MMP-2 and MMP-9 activity in fibroblasts
}

\author{
Young-Ah Jang ${ }^{1} \cdot$ Jin-Tae Lee $^{1}$ (D) \\ 섬유아세포에서의 MMP-2 및 MMP-9 활성 억제에 의한 베르베린의 \\ 항주름 효과
}

장영아 ${ }^{1} \cdot$ 이진태 ${ }^{1}$

Received: 31 July 2017 / Accepted: 14 November 2017 / Published Online: 31 March 2018

(C) The Korean Society for Applied Biological Chemistry 2018

\begin{abstract}
We analyzed the antioxidant and anti-wrinkle activities of berberine, isolated from dried rhizome of Coptis japonica Makino, to determine its cosmetic potential. We performed the 3[4,5-dimethylthiazol]-2-yl]-2,5-diphenyl-tetrazoliumbromide (MTT) assay to evaluate the toxicity of the berberine. We also measured the ROS and hyaluronic acid production, and expression of MMP2, MMP-9, TIMP-1, TIMP-2, and tumor necrosis factor-alpha (TNF- $\alpha$ ) to evaluate the antioxidant and anti-wrinkle activities of berberine, respectively. The cytotoxicity of ultraviolet light, in presence of berberine, was measured by the MTT assay using CCD-986sk fibroblasts, and no cytotoxicity was observed at concentrations less than $25 \mu \mathrm{g} / \mathrm{mL}$. We also found that berberine decreased ROS production in a concentration-dependent manner and promoted the synthesis of hyaluronic acid. Further, berberine reduced the protein levels and mRNA expression of MMP-2 and MMP-9, which are associated with wrinkle formation, and increased the expression of TIMP-1 and TIMP-2. In addition, the inhibitory effect of berberine on TNF- $\alpha$, known as pro-inflammatory cytokine, was inhibited by TNF- $\alpha$ gene in a concentrationdependent manner. These results suggest that berberine holds
\end{abstract}

Jin-Tae Lee $(\bowtie)$

E-mail: jtleecosmetics@gmail.com

${ }^{1}$ Department of Cosmeceutical Science, Daegu Haany University, Gyeongbuk 38540, Republic of Korea

This is an Open Access article distributed under the terms of the Creative Commons Attribution Non-Commercial License (http://creativecommons. org/licenses/by-nc/3.0/) which permits unrestricted non-commercial use, distribution, and reproduction in any medium, provided the original work is properly cited. cosmetic value owing to its antioxidant activity, by inhibiting ROS production and anti-wrinkle activity by reducing MMP-2 and MMP-9 and increasing TIMP-1 and TIMP-2 expression.

Keywords Anti-aging - Berberine $\cdot$ Matrix metalloproteinases · Reactive oxygen species - Tissue inhibitor of matrix metalloproteinases

\section{서 론}

피부노화는 그 요인에 따라 내재적 노화(intrinsic aging)와 외인 적 노화(extrinsic aging)로 구분할 수 있다. 내재적 노화는 세포 외 기질(extracellular matrix)의 산화적 스트레스에 의한 세포 및 조직의 손상, telomere 단축 및 apoptosis 장애로 인해 피부건조 및 탄력소실의 특징을 일으킨다(Meinhard 등, 2001; Jeong과 $\operatorname{Kim}$ 2006). 외인적 노화의 원인은 햇빛에 의한 피부노화가 주 요한 인자이며 흡연, 음주, 스트레스 등의 요인도 포함된다 (Farage 등, 2008). 피부는 자외선에 노출되면 홍반, 부종, 색소 침착 및 말초혈관을 확장시키는 특징을 나타내며 진피조직의 섬 유아세포에서 superoxide anion, peroxide, singlet oxygen 등을 포함하는 인체에 유해한 활성산소(ROS, reaction oxygen species)를 생성하게 된다(Chung 2003). 과다하게 생성된 ROS 는 직간접적으로 $\mathrm{DNA}$ 변성, 세포막의 파괴를 일으켜 암, 당뇨 병 등 각종 성인병을 일으키며 피부결합 조직성분인 collagen감 소에 원인이 되는 MMPs (matrix-metalloproteinase)를 증가시킨 다(Yaar와 Gilchrest 2007). MMPs 는 아연(Zn) 의존성 중성 단백질 분해효소로 collagen의 분해 및 변형에 관여하여 피부노 
화를 일으키는 과정에서 중요한 역할을 한다(Kim 등, 2011; Hwang 등, 2014). MMP는 gelatinase, collagenase, stromelysin 및 막결합성 $\mathrm{MMP}$ 군으로 분류 되며 최근 연구에 의하면 인간 에서 26가지의 MMPs가 존재한다고 보고되었다(Greenlee 등, 2007). $\mathrm{MMP}$ 중, $\mathrm{MMP}-1$ 은 섬유성 콜라겐 1형과 3형의 콜라겐 을 1차로 분해하며 MMP-2와 MMP-9은 gelatinase군으로서 MMP-1에 의해 분해된 콜라겐 조각들을 더 잘게 분해하여 피 부노화에 주요한 역할을 한다(Moon 등, 2008). MMP-2는 분자 량 $72 \mathrm{kDa}$ 크기로 다양한 종류의 세포에서 항시 발현되어 laminin과 기저막을 형성하는 type IV collagen을 분해하는 효 소로 역할을 하며, MMP-9은 분자량 $92 \mathrm{kDa}$ 으로 각종 염증성 자극에 의해 유도되고 기저막 성분을 분해하는 것으로 알려져 있다(Girolamo 등, 1997; Wong 등, 2002). 특히 MMP-9은 tumor necrosis factor-alpha (TNF- $\alpha)$, interleukin-6와 같은 내 독소 염증성 매개체 자극으로 발현이 증가하는 것이 특징이며 섬유아세포에서 collagen의 분해를 촉진시킨다(Sanceau 등, 2002). MMPs의 활성을 조절하는 인자로 알려진 MMPs의 조직 억제인자(tissue inhibitors of MMPs, TIMPs)는 $21-30 \mathrm{kDa}$ 의 분자량을 가지며 TIMP-1, TIMP-2, TIMP-3, TIMP-4 등 4종이 알려져 있으며 다양한 유형의 세포에 의해 발현된다(Iwata 등, 1996; Ries 2014). TIMPs는 MMP와 비 공유적인 결합을 하여 $\mathrm{MMP}$ 의 기능을 억제하는 것으로 알려져 있고, TIMP-1은 MMP-9과, TIMP-2는 MMP-2와 각각 결합하여 세포 간 기질의 파괴와 재형성 간의 균형을 조절하는 역할을 한다(Johnson 등, 1994). 이와 같이 최근 천연물을 이용한 항노화 화장품 소재 개 발에 있어서 MMPs와 TIMPs의 연관성을 검증하는 연구가 지 속적으로 진행되고 있다. 황련(Coptis japonica Makino)은 미나 리아재비과(Ranunculaceae)에 속하는 다년생 초목으로 주요성분 으로는 berberine $5.20-7.69 \%$, coptisine, epiberberine, palmatine, jateorrhizine, magnoflorine, worenine, ferulic acid 등이 있으며 이외에도 상당수의 미량원소인 $\mathrm{Fe}, \mathrm{Cu}, \mathrm{Zn}, \mathrm{Mn}$ 등이 보고되어 있다(An 등, 2005; Zi-Min 등, 2017). 황련에 관련된 연구는 이러한 성분들의 개별 효과 및 약리기전에 대해 활발히 진행되 어 왔으며 주성분인 isoquinoline계 alkaloid인 berberine은 용혈 성연쇄구균, 흥막염균, 폐렴쌍구균, 콜레라균, 탄저병균등에 대 해 강한 억제효과가 있다고 보고 되어있다(Yamahara 1976). 함 영증에 관한 연구는 여러 조건 하에서 다양하게 입증되어 왔으 며(Choi와 Lee 2006; Chae 등, 2009) 최근에는 황련의 주 효 능 이외의 진통 효과 $(\mathrm{Li}$ 등, 2006) 치은 섬유모세포 증식 효과 (Yoo 1996) 등이 입증되었다. 이전 연구에서 berberine 물질에 관한 약리학적 효능이 충분히 진행되었으나, 항주름 화장품 소 재개발을 위한 MMPs와 그 조절인자 TIMPs의 연관성에 대한 검증은 미비하였다. 본 연구에서는 황련에서 분리한 berberine 을 이용하여 항산화 및 항주름 효과에 대해 검증하였다.

\section{재료 및 방법}

\section{식물재료}

본 실험에 사용한 황련은 2016년 경북 의성군 봉양면 (주)옴니 허브로 부터 건조된 시료를 구입하였으며, 깨끗이 세척한 뒤 실 험재료로 사용하였다. 각 표본 및 추출물은 대구한의대학교 화
장품약리학과 피부면역약리 실험실에 보관하고 있다.

\section{시료추출}

황련 열수 추출액 $(2.5 \mathrm{~g})$ 에 $25 \mathrm{~mL}$ 물을 넣고 3시간씩 3회 환류 추출 한 다음 filter paper (Whatman No. 2, Tokyo, Japan)를 사용하여 여과한 후 얻은 추출물 $2.25 \mathrm{~g}$ 을 Sephadex LH20 컬 럼 크로마토그래피로 분리하였다. 용매는 $\mathrm{H}_{2} \mathrm{O}-\mathrm{MeOH}$ 을 $0-100 \%$ 까지 농도로 높였으며 $\mathrm{TLC}$ 를 실시하여 4개의 분획(Fr.1, Fr.2, Fr.3, Fr.4)으로 나누었다. Fr.3으로 부터 MCI-gel CHP 20 (75$150 \mu \mathrm{m}$, Mitsubishi Chemical, Tokyo, Japan)에서 Middle pressure liquid chromatography (MPLC) $\mathrm{H}_{2} \mathrm{O}-\mathrm{MeOH}, 0-100 \%$ 을 이용하여 Fr.3-1, Fr.3-2, Fr.3-3으로 각각 나누었다. Fr.3-3은 MPLC를 이용하여 $\mathrm{H}_{2} \mathrm{O}-\mathrm{MeOH}, 20-100 \%$ 조건에서 YMC-gel ODS-A-HG $(50 \mu \mathrm{m}, \mathrm{YMC}$ group, Kyoto, Japan)을 통해 최종 적으로 berberine의 화합물 $(20 \mathrm{mg})$ 을 얻었고 실험에 사용하였다.

\section{Berberine}

yellow amorphous powder, ${ }^{1} \mathrm{H}-\mathrm{NMR}\left(600 \mathrm{MHz}, \mathrm{CD}_{3} \mathrm{OD}\right): \delta$ $9.74(1 \mathrm{H}, \mathrm{s}, \mathrm{H}-8), 8.65$ (1H, s, H-13), 8.09 (1H, d, $J=$ $8.3 \mathrm{~Hz}, \mathrm{H}-11), 7.98(1 \mathrm{H}, \mathrm{d}, J=8.4 \mathrm{~Hz}, \mathrm{H}-12), 7.62(1 \mathrm{H}, \mathrm{s}$, $\mathrm{H}-1), 6.94(1 \mathrm{H}, \mathrm{s}, \mathrm{H}-4), 4.89(\mathrm{H}-6), 6.09\left(2 \mathrm{H}, \mathrm{s}, \mathrm{OCH}_{2} \mathrm{O}\right)$, $4.18\left(3 \mathrm{H}, \mathrm{s}, 9-\mathrm{OCH}_{3}\right), 3.23(2 \mathrm{H}, \mathrm{t}, J=6.4 \mathrm{~Hz}, \mathrm{H}-5), 4.08$ $\left(3 \mathrm{H}, \quad \mathrm{s}, 10-\mathrm{OCH}_{3}\right),{ }^{13} \mathrm{C}-\mathrm{NMR}\left(150 \mathrm{MHz}, \mathrm{CD}_{3} \mathrm{OD}\right): 150.9$ (C10), 150.8 (C-3), 148.7 (C-2), 145.2 (C-9), 144.5 (C-8), 138.4 (C-13a), 133.9 (C-12a), 130.7 (C-4a), 126.8 (C-11), 123.3 (C-12), 122.1 (C-8a), 120.6 (C-13b), 120.3 (C-13), 108.2 (C-4), 105.3 (C-1), $102.5\left(\mathrm{OCH}_{2} \mathrm{O}\right), 61.3$ (C-9), 56.4 (C-10), 56.0 (C-6), 27.0 (C-5).

\section{세포 주 배양 및 세포독성 측정}

세포 독성 측정에 사용된 섬유아세포 CCD-986sk는 American Culture Collection (Manassas, VA, USA)에서 구입하여 사용하 였다. 세포 독성 측정 및 배양을 위한 배지조성을 위해 dulbecco's modified eagle medium (DMEM), fetal bovine serum (FBS), penicillin/streptomycin, 0.4\% trypan blue stain 은 Gibco BRL Co. (Rockville, NE, USA)에서 구입하였으며, 3-[4,5-dimethylthiazol]-2-yl]-2,5-diphenyl-tetrazoliumbromide (MTT)는 Sigma Chemical Co. (St. Louis, MO, USA)에서 구 입하였다. MMP-2, MMP-9, TNF- $\alpha$, TIMP-1, TIMP-2, GAPDH 의 primary antibody와 secondary antibody는 Santa Cruz (Santa Cruz, CA, USA)에서 구입하였다. 본 실험에 이용한 각 세포의 배양은 $10 \% \mathrm{FBS}$ 와 $1 \%$ penicillin/streptomycin (100 U/ $\mathrm{mL}$ )을 첨가한 $\mathrm{DMEM}$ 배지를 사용하였으며, $37^{\circ} \mathrm{C}, 5 \% \mathrm{CO}_{2}$ incubator에 적응시켜 계대 배양하였다.

\section{MTT assay에 의한 세포 독성 측정}

CCD-986sk세포를 96 well plate에 $5 \times 10^{3}$ cells/well이 되게 $0.18 \mathrm{~mL}$ 분주하고, berberine을 각각 $6.25,12.5,25,50,100$ $\mu \mathrm{g} / \mathrm{mL}$ 의 농도로 조제하여 $0.02 \mathrm{~mL}$ 첨가한 후 $37^{\circ} \mathrm{C}, 5 \% \mathrm{CO}_{2}$ incubator에서 24시간 배양하였다. 여기에 $5 \mathrm{mg} / \mathrm{mL}$ 농도로 제 조한 MTT 용액 $0.02 \mathrm{~mL}$ 를 첨가하여 4시간 배양한 후 배양액 을 제거하고 각 well당 $\mathrm{DMSO} 0.15 \mathrm{~mL}$ 를 가하여 실온에서 15 
분간 반응 시킨 뒤 ELISA reader로 $540 \mathrm{~nm}$ 에서 흡광도를 측정 하였다. 세포 독성 측정은 시료용액의 첨가군와 무첨가군의 흡 광도 감소율로 나타내었다.

\section{ROS (Reaction Oxygen Species) 생성량 측정}

CCD-986sk 세포를 배양한 후 96 well plate에 $2 \times 10^{5}$ cell/well 로 접종하고 24시간 안정화하였다. 동일 배지로 교체한 후 20 $\mathrm{mJ} / \mathrm{cm}^{2}$ 의 UVB로 자극 한 뒤, berberine을 $5,10,25 \mu \mathrm{g} / \mathrm{mL}$ 의 농도로 희석하여 처리한 후 48시간 배양하였다. 그 후 제조사 의 매뉴얼(Thermo Fisher Scientific, Waltham, MA, USA)에 따라 ROS Glo $\mathrm{H}_{2} \mathrm{O}_{2}$ assay를 수행하였다.

\section{HA (Hyaluronic acid) 생성량 측정}

세포배양액 내의 HA 생성량은 ELISA kit (Echelon, Salt Lake City, UT, USA)를 이용하여 측정하였다. CCD-986sk 세포는 $\mathrm{DMEM}$ 배지를 이용하여 $5 \times 10^{4}$ cells $/ \mathrm{mL}$ 로 조절한 후 48 well plate에 접종하고, $5 \% \mathrm{CO}_{2}$ incubator에서 24시간 배양하였다. 세포에 $20 \mathrm{~mJ} / \mathrm{cm}^{2}$ 의 $\mathrm{UVB}$ 를 자극한 뒤 $5,10,25 \mu \mathrm{g} / \mathrm{mL}$ 의 berberine을 처리하여 48시간 배양하였다. 배양이 끝난 후 상등 액을 취하여 $\mathrm{HA}$ 를 측정하였다.

\section{Western Blot을 이용한 단백질의 발현 측정}

CCD-986sk 세포를 $1 \times 10^{5}$ cell/wells로 6 well plate에 분주하여 24시간 배양한 후에 $20 \mathrm{~mJ} / \mathrm{cm}^{2}$ 의 UVB로 자극 한 뒤 berberine 을 농도별 $(5,10,25 \mu \mathrm{g} / \mathrm{mL})$ 로 처리하여 48 시간 배양하였다. 세 포를 RIPA buffer (Pierce, IL, USA)로 용해시키고 원심분리하 여 $\left(12,000 \mathrm{rpm}, 4{ }^{\circ} \mathrm{C}, 30 \mathrm{~min}\right)$ 세포막 성분들을 제거하여 상층 액을 얻었다. Bradford assay로 단백질을 정량하였으며, $20 \mu \mathrm{L}$ 의 단백질을 $10 \%$ 의 sodium dodecyl sulfate polyacrylamide gel electrophoresis를 이용하여 전기 영동한 후, 항체의 비특이 적 결합을 억제시키기 위해 PVDF membrane에 옮긴 다음 60 $\mathrm{V}$ 에서 2시간 이상 transfer하였다. 5\% skim milk가 함유된 tris 완충 용액으로 1시간 blocking 한 후, MMP-2, MMP-9, TNF$\alpha$, TIMP-1, TIMP-2, $\beta$-actin 각각의 1 차 및 2 차 항체와 반응 시켰다. 반응 후 Immobilon Western Chemiluminescent HRP substrate (Millipore, MA, USA)를 이용하여 60분간 반응시킨 후 LAS 4000 분석기(Fuji Film Life Science, Tokyo, Japan) 을 이용하여 현상하였다.

\section{유전자 발현 분석을 위한 RNA 분리 및 RT-PCR}

Berberine의 MMP-2, MMP-9, TNF- $\alpha$, TIMP-1, TIMP-2, $\mathrm{GAPDH}$ 유전자 발현에 미치는 영향을 관찰하기 위해 $\mathrm{CCD}$ 986sk 세포를 6 well에 $1 \times 10^{5}$ cells/well에 되도록 분주하고 48
시간 동안 배양하였다. 배지를 제거한 후 $20 \mathrm{~mJ} / \mathrm{cm}^{2}$ 의 UVB로 자극 한 뒤, berberine을 농도별 $(5,10,25) \mu \mathrm{g} / \mathrm{mL}$ 로 처리하여 48시간 배양하였다. 그 후 total RNA는 PBS로 3번 세척하고 세포를 수확한 다음, trizol reagent (Invitrogen, Carlsbad, CA, USA)을 이용하여 분리하였다. Total RNA $2 \mu \mathrm{g}$ 과 PCR primer oligonucleotide를 RT-PCR mixer와 혼합하고 RT-PCR을 시행하 였다. Lysis buffer를 이용하여 CCD-986sk 세포를 용해시키고, $4{ }^{\circ} \mathrm{C} 12,000 \mathrm{rpm}$ 에서 20 분간 원심 분리하였다. MMP-2, MMP9, TNF- $\alpha$, TIMP-1, TIMP-2, GAPDH의 염기서열은 Table 1 과 같다. $\mathrm{RT}$ 의 조건은 $42{ }^{\circ} \mathrm{C}$ 에서 1 시간 방치하여 $\mathrm{cDNA}$ 를 제 조하고 $94{ }^{\circ} \mathrm{C}$ 에서 5 분간 방치하여 reverse transcriptase를 불활 성화 시켰다. 이후의 $\mathrm{PCR}$ 조건은 94에서 30초(denaturation), $50{ }^{\circ} \mathrm{C}$ 에서 30 초(annealing), $72{ }^{\circ} \mathrm{C}$ 에서 90 초(extension)의 반응을 30 회 반복하는 것을 기본으로 target cDNA 종류에 따라 최적 의 조건으로 조절하였다. 증폭된 $\mathrm{cDNA}$ 는 $1.2 \%$ agarose gel을 사용한 전기영동으로 분리하고 LAS 4000 image analyzer으로 확인하였다.

\section{통계처리}

결과 통계처리는 SPSS 10.0 을 사용하였으며, 유의차 검증은 분 산분석(ANOVA: analysis of variance)프로그램을 이용하여 $\mathrm{t}$ test를 이용하여 통계적 유의수준 $p<0.05,0.01$ 에서 검증하였다.

\section{결과 및 고찰}

\section{세포독성 평가}

Berberine의 세포독성 여부를 확인하기 위해 $(6.25,12.5,25,50$, 100) $\mu \mathrm{g} / \mathrm{mL}$ 의 농도를 세포에 처리한 결과, $25 \mu \mathrm{g} / \mathrm{mL}$ 이하의 농도에서 세포생존율이 $90 \%$ 이상으로 나타나 CCD-986sk세포 에 독성이 없는 것으로 사료되어 $25 \mu \mathrm{g} / \mathrm{mL}$ 이하의 농도로 실험 을 진행하였다(Fig. 1).

\section{ROS 생성 억제효과}

활성산소종(ROS)은 고 에너지 복사선, 광증감반응 및 일부 효 소반응과 같은 과정을 거쳐 세포와 조직에서 생성되는데, 생체 내에서 과잉의 지방산화, DNA손상 및 단백질 변성 등을 초래 하는 것으로 알려져 있다(Shindo등, 1993). 많은 양의 자외선에 노출되면 피부에는 높은 농도의 활성산소종이 생성되며 피부세 포 내에서의 신호전달 과정에 영향을 미쳐 피부주름과 관련된 전사인자들을 활성화 시킨다(Pentland등, 1995; Park등, 2010). CCD-986sk 세포에 대한 UVB 조사에 따른 ROS 생성량을 측 정한 결과, $\mathrm{UVB}$ 를 $20 \mathrm{~mJ} / \mathrm{cm}^{2}$ 의 선량을 조사한 그룹은 대조군

Table 1 The sequences of the primers of MMP-2, MMP-9, TNF- $\alpha$, TIMP-1, TIMP-2 and GAPDH

\begin{tabular}{ccc}
\hline \hline Gene & Sense & Antisense \\
\hline MMP-2 & GCATGGCTCGCCTACAGACT & GCAGGGAGGGAGGCAGAGGA \\
MMP-9 & ATGGCCCCACTGAAGATGCT & TGAACACCAACGGTGGAGGT \\
TNF- $\alpha$ & AAGCTTCATGGTGATGCGAC & TCAAGCAGAAGAGGAAGGCA \\
TIMP-1 & ACCTAGCGGACCCGAAATAA & TGGAACAGCAGGAAAAGCAC \\
TIMP-2 & CACTGGGGTTGGGAGGTAGT & GCTCTCATGATGCTACCCGA \\
GAPDH & CCACCCAGTACAGCGTCAAC & CATGGCTTCTGTCGCTCT \\
\hline
\end{tabular}




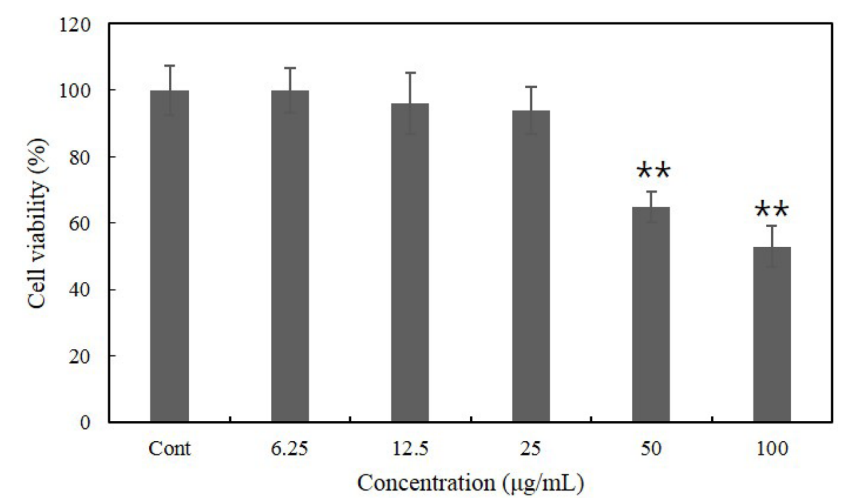

Fig. 1 Cell viability of berberine on CCD-986sk human fibroblast cells by MTT assay. The cells were treated various concentrations of sample. The results were expressed as the average of triplicate. ${ }^{*} p<0.05$, ${ }^{* *} p<0.01$ compared with control

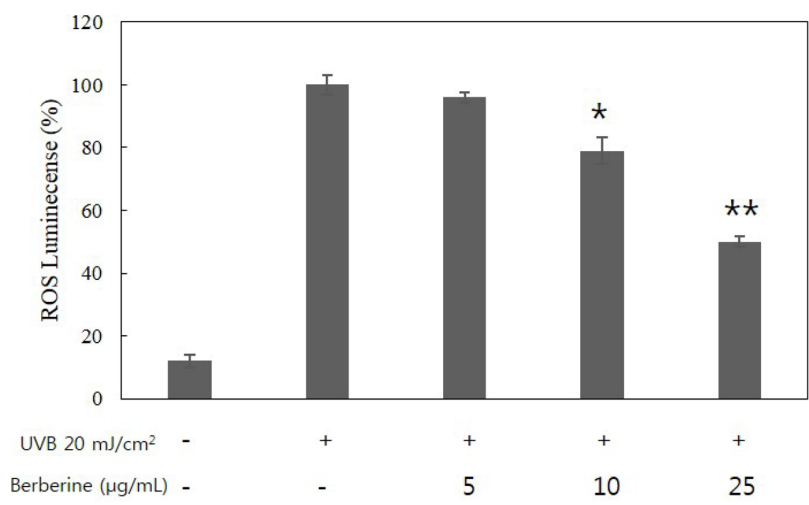

Fig. 2 Effect of berberine in the expression of ROS in the UVB-induced CCD-986sk human fibroblast cells. Cells were treated for $48 \mathrm{~h}$ with berberine $(5,10,25 \mu \mathrm{g} / \mathrm{mL})$ during UVB $\left(20 \mathrm{~mJ} / \mathrm{cm}^{2}\right)$ activation. The results were expressed as the average of triplicate. ${ }^{*} p<0.05,{ }^{*} p<0.01$ compared with control

에 비해 ROS 생성량이 약 2 배 증가 되었다. UVB 조사 후 berberine을 농도별 $(5,10,25) \mu \mathrm{g} / \mathrm{mL}$ 로 처리한 군은 농도의존 적으로 $\mathrm{ROS}$ 생성량이 감소되었으며 특히 $25 \mu \mathrm{g} / \mathrm{mL}$ 농도에서 는 $40 \%$ 이상의 높은 감소를 보였다(Fig. 2).

\section{HA (Hyaluronic acid) 생성량 측정}

Hyaluronic acid (HA)는 친수성 고분자 물질로서 피부 진피층 과 연골조직 등에서 주로 발견되며, 피부의 수분함량을 유지시 키고 콜라겐 및 엘라스틴과 함께 피부 탄력과 구조를 유지하는 필수적인 요소이다(Kim등, 2007). $\mathrm{HA}$ 는 주로 각질형성세포 및 섬유아세포의 hyaluronic acid synthase에 의해 합성되어 세포 외 기질에 저장되고 UVB 및 산화적 스트레스에 의한 $\mathrm{HA}$ 의 결함은 표피의 위축, 주름형성, 피부 수분량 감소, 탄력성 저하 등 피부노화를 일으키는 것으로 알려져 있다(Dübe 등, 2001; Song등, 2013).

Berberine이 피부 수분량 및 탄력성에 영향을 미치는지 알아 보기 위하여 CCD-986sk 세포에 UVB조사 후 농도별 $(5,10$, 25) $\mu \mathrm{g} / \mathrm{mL}$ 시료를 처리하여 Hyaluronic acid 생성 효과를 측정

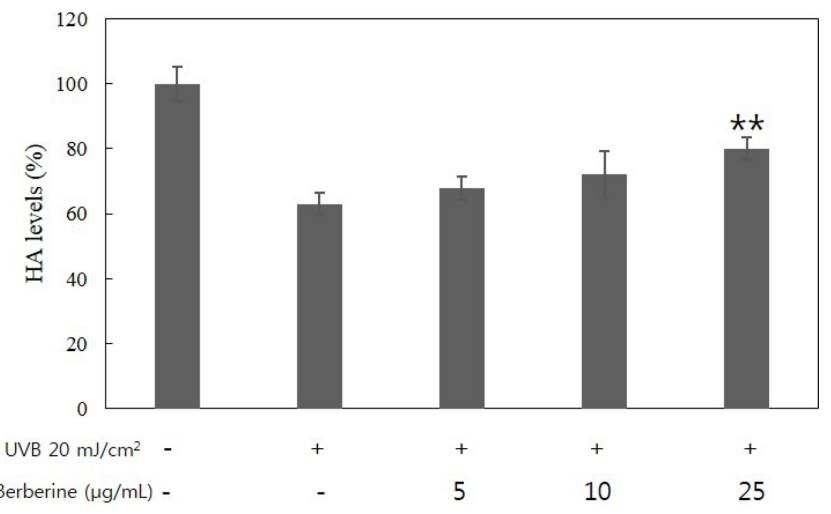

Fig. 3 Effect of berberine in the expression of hyaluronic acid in the UVB-induced CCD-986sk human fibroblast cells. Cells were treated for $48 \mathrm{~h}$ with berberine $(5,10,25 \mu \mathrm{g} / \mathrm{mL})$ during UVB $\left(20 \mathrm{~mJ} / \mathrm{cm}^{2}\right)$ activation. The results were expressed as the average of triplicate. ${ }^{*} p<0.05,{ }^{* *} p<0.01$ compared with control

하였다. 그 결과 berberine을 처리하였을 때 hyaluronic acid 양 은 유의적으로 농도의존적 증가를 나타내었으며 이는 berberine 이 피부 보습력 개선 및 피부노화 방지에 효과가 있는 것으로 확인되었다(Fig. 3).

MMP-2, MMP-9의 protein 합성 및 mRNA 발현 측정 결과 광노화 된 피부는 세포 외 기질을 분해하는 MMP-1, -2, -9과 같은 MMPs의 발현 증가로 피부건조증과 주름이 형성된다. Berberine이 섬유아세포 내 UVB 자극에 의해 발현이 증가되는 MMP-2, -9에 미치는 영향을 알아보기 위하여 western blot analysis를 시행하였다. 그 결과 섬유아세포에 처리된 berberine 의 농도가 증가할수록 처리하지 않은 군에 비해 MMP-2, -9의 protein level 발현이 억제되었으며, MMP-2는 $(10,25) \mu \mathrm{g} / \mathrm{mL}$, MMP-9은 $25 \mu \mathrm{g} / \mathrm{mL}$ 농도에서 유의성 있게 감소하는 것을 확인 하였다(Fig. 4A), 또한 berberine의 처리에 따른 mRNA 발현을 관찰하고자RT-PCR로 수행한 결과, house keeping gene 인 $\mathrm{GAPDH}$ 발현을 기준으로 수치 한 결과 농도가 높아짐에 따라 MMP-2, -9의 발현이 감소되었고 $25 \mu \mathrm{g} / \mathrm{mL}$ 농도에서 유의성을 확인하였다(Fig. 4B). 이와 같이 berberine은 MMPs의 발현을 저해함으로써 노화에 따른 주름생성을 억제할 수 있는 화장품 소재로의 가능성을 제시하고 있다.

\section{TIMP-1, -2 protein 합성 및 mRNA 발현 측정 결과}

주름개선 화장품 소재는 피부 노화를 방지하기 위해 진피의 상 당부분을 차지하는 콜라겐의 분해를 억제하는 소재를 찾는 것 이 핵심이며 이에 따라 항주름 소재의 MMPs와 TIMPs의 단백 질 발현 및 $\mathrm{mRNA}$ 단계에서 조절을 확인하는 것이 중요하다. TIMPs (21-30 kDa)는 조직 내에서 MMPs 활성을 조절하는 주 요한 내재인자로 알려져 있으며 노화가 진행되면 MMPs 발현 은 증가되고 TIMPs의 발현은 줄어들어 피부탄력을 감소시키고 피부주름을 생성시키는 것으로 알려져 있다(Uzui 등, 2002; Lambert 등, 2004).

Berberine의 섬유아세포에서의 TIMP-1, -2의 활성을 관찰하 고자 CCD-986sk 세포에 UVB조사 후 농도별 $(5,10,25) \mu \mathrm{g} /$ 

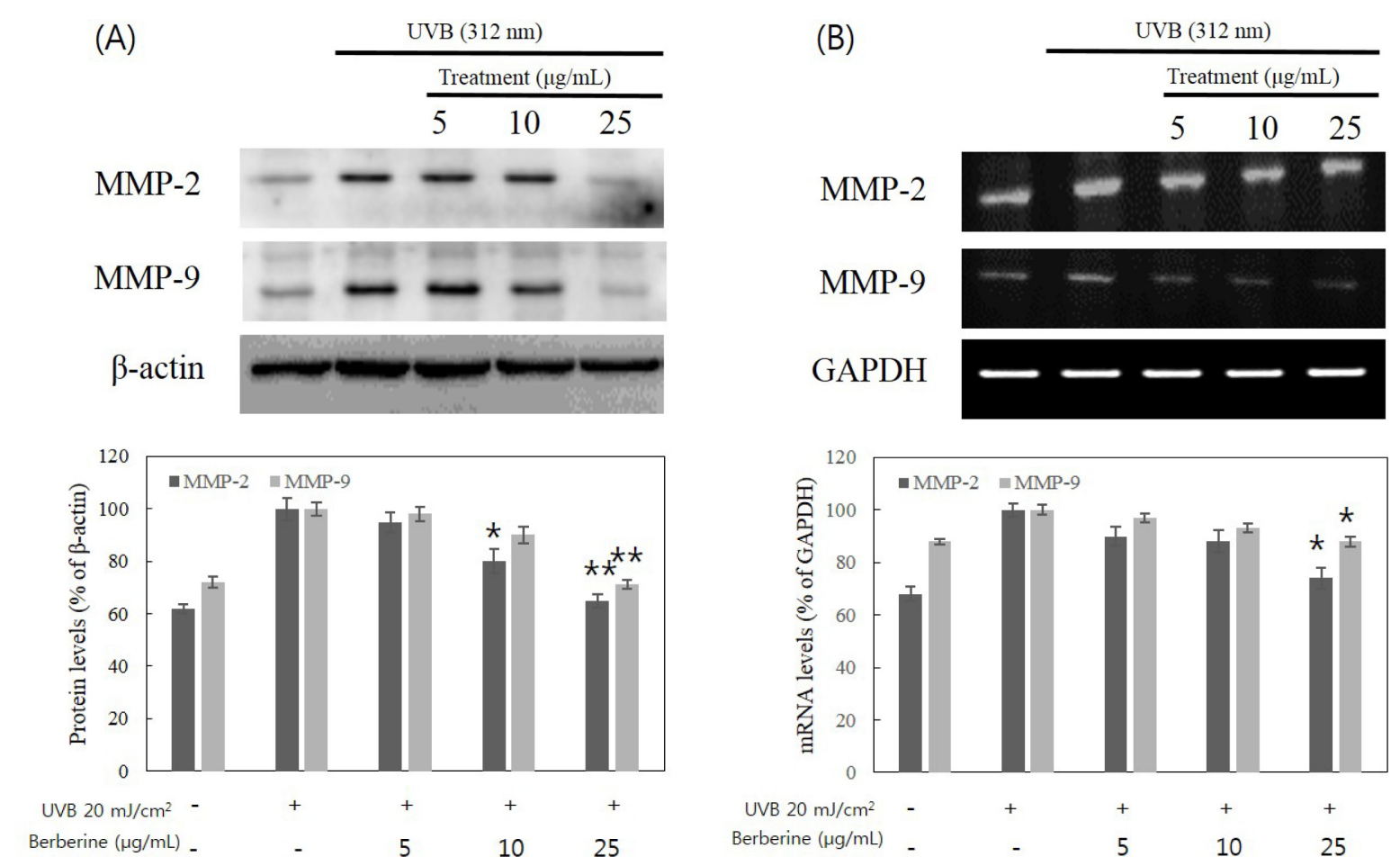

Fig. 4 Expressions of MMP-2 and MMP-9 evaluated by protein level (A) and mRNA level (B) in CCD-986sk fibroblasts after berberine treatment. CCD-986sk cells $\left(1 \times 10^{5}\right)$ were grown and exposed to UVB for $1 \mathrm{~min}$; the cells were then subject to 5,10 and $20 \mu \mathrm{g} / \mathrm{mL}$ of berberine treatment. The protein and mRNA levels were normalized using Image Quant software
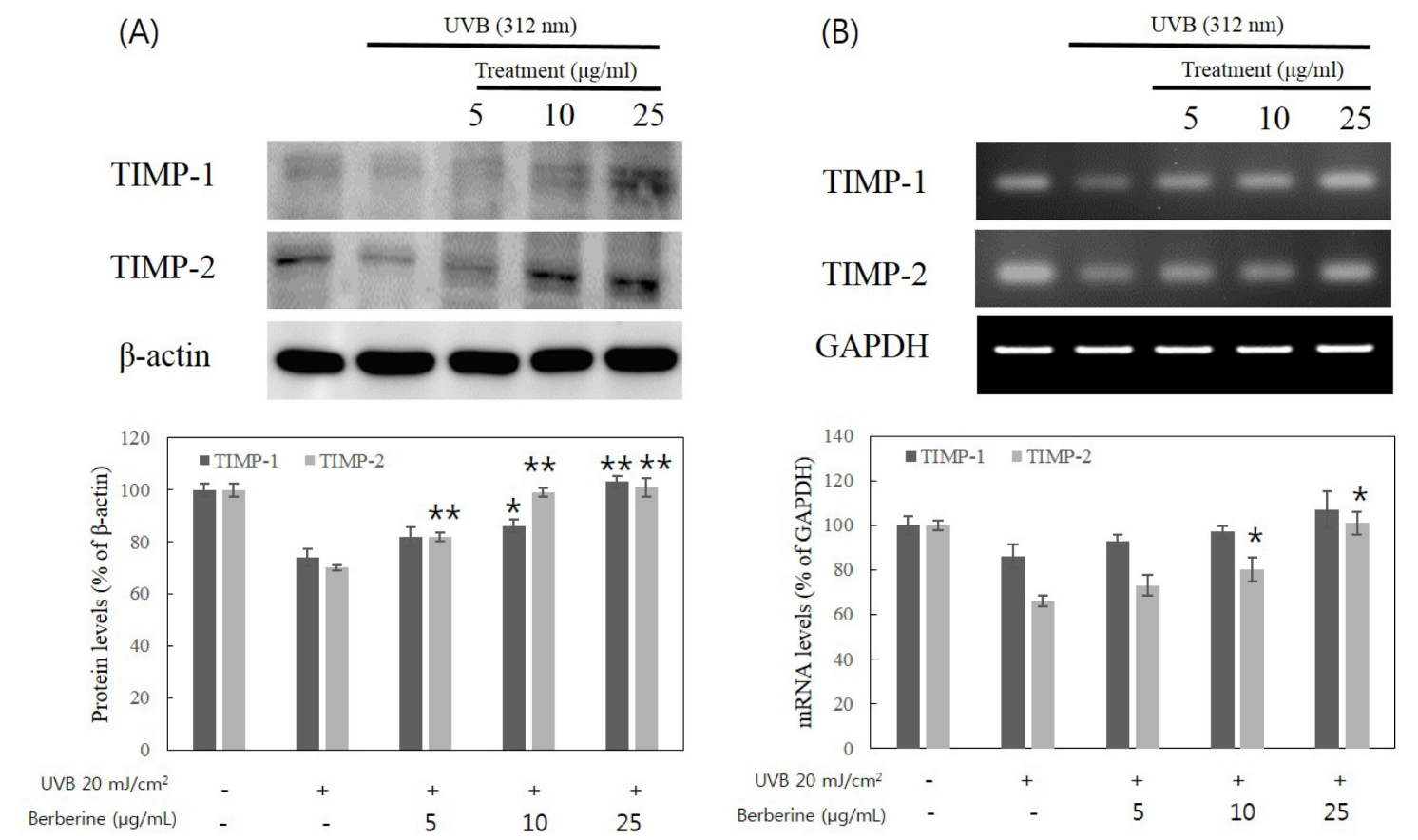

Fig. 5 Expressions of TIMP-1 and TIMP-2 evaluated by protein level (A) and mRNA level (B) in CCD-986sk fibroblasts after berberine treatment. CCD-986sk cells $\left(1 \times 10^{5}\right)$ were grown and exposed to UVB for $1 \mathrm{~min}$; the cells were then subject to $5,10 \mathrm{and} 20 \mu \mathrm{g} / \mathrm{mL}$ of berberine treatment. The protein and mRNA levels were normalized using Image Quant software 
(A)

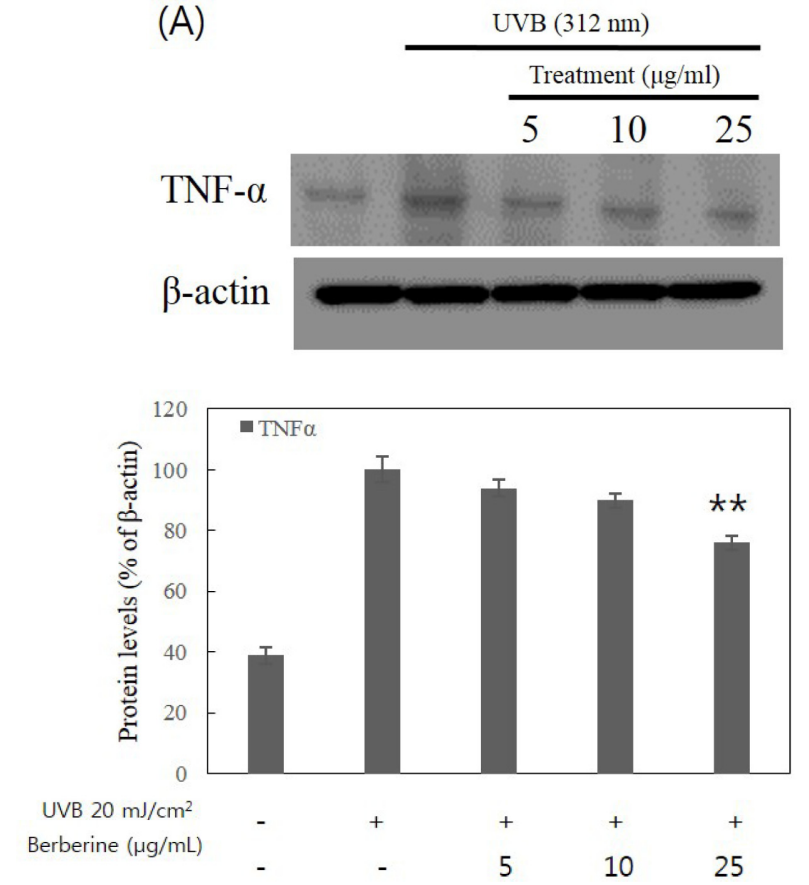

(B)

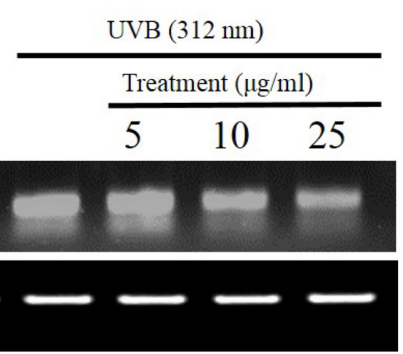

GAPDH

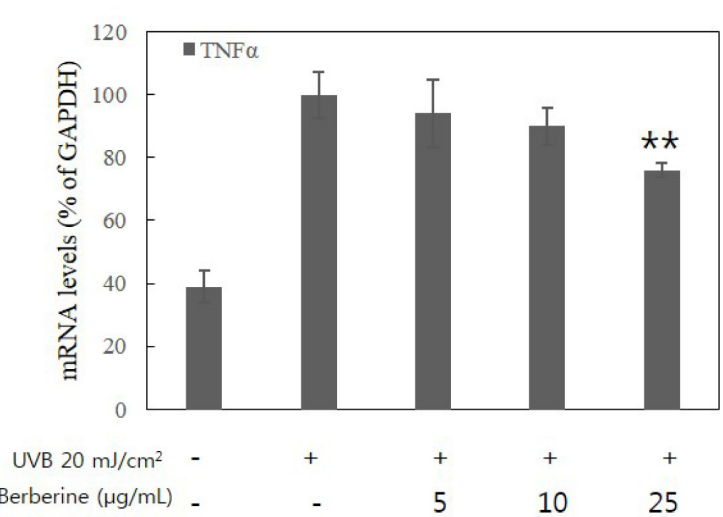

Fig. 6 Expressions of TNF- $\alpha$ evaluated by protein level (A) and mRNA level (B) in CCD-986sk fibroblasts after berberine treatment. CCD-986sk cells $\left(1 \times 10^{5}\right)$ were grown and exposed to UVB for $1 \mathrm{~min}$; the cells were then subject to 5,10 , and $20 \mu \mathrm{g} / \mathrm{mL}$ of berberine treatment. The protein and mRNA levels were normalized using Image Quant software

$\mathrm{mL}$ 시료를 처치하여 48시간 배양 후 단백질을 western blot analysis를 시행하였다(Fig. 5A). 그 결과 UVB군에서 TIMP-1, -2 발현을 현저히 감소시켰으며, berberine처리 후 농도의존적으 로 TIMP-1, -2 단백질 발현을 증가시켰다. RT-PCR 결과에서도 TIMP-1, -2의 mRNA 발현량이 농도의존적으로 감소되는 것을 확인하였다(Fig. 5B). TIMPs의 주된 생물학적 작용이 MMPs를 억제하는 것이며 그 중 TIMP-1은 MMP-9을, TIMP-2는 MMP-2에 각각 대항하여 피부 기저층의 기질분해작용을 억제 한다는 보고가 있다(Terada 등, 1996; Gong 등, 2000). 본 실 험 결과에 따라 berberine에 의한 단백질 및 $\mathrm{mRNA}$ 발현에서 MMP-2와 MMP-9은 감소하였고, TIMP-1과 TIMP-2는 증가함 을 보여 berberine이 CCD-986sk 세포내에서 TIMP-1, -2 발현 을 조절하여 MMP-2, -9을 감소시킴으로써 콜라겐 분해를 억제 하는 것으로 추측된다.

\section{Inflammatory cytokine TNF- $\alpha$ 발현 측정 결과}

MMPs의 활성은 UVB, hormones, growth factors, cytokines에 의해 조절되며 특히 UVB에 의한 MMPs발현 증가는 세포 내 다양한 신호전달을 통해 활성화되어 inflammatory cytokine을 발현시켜 ROS를 생성시킨다(Hwang 등, 2012). TNF- $\alpha$ 는 강력 한 pro-inflammatory cytokine으로서 염증반응의 매개체로 작용 하며, MMPs와 TIMPs의 과정에 관여하여 노화를 일으키는 것 으로 알려져 있다(Seo 등, 2004).

Berberine이inflammatory cytokine의 발현에 영향을 주는지 알 아보기 위해 섬유아세포에 UVB를 조사 후 berberine을 농도별 $(5,10,25) \mu \mathrm{g} / \mathrm{mL}$ 로 처리한 결과 UVB군에서는 TNF- $\alpha$ 가 현 저하게 증가되었으며 berberine을 처리한 군에서는 TNF- $\alpha$ 단백
질 및 mRNA 발현이 낮아졌음을 확인하였다(Fig. 6).

$\mathrm{TNF}-\alpha$ 는 섬유아세포를 포함한 많은 조직에서 MMP-9 발현 을 유도하여 elastin, fibronectin, gelatin을 감소시키는 것으로 알려져 있다(Muller 등, 1993). 본 실험결과에도 UVB 단독 처 리한 군에서 TNF- $\alpha$ 와 MMP-9 발현이 증가되었으며 berberine 을 처리한 군은 TNF- $\alpha$ 와 MMP-9의 발현이 동일하게 감소하는 것으로 나타났다.

\section{초 록}

우리는 황련에서 분리된 베르베린의 화장품소재로의 활성을 평 가하기 위해 항산화와 항주름 효능을 분석하였다. 시료의 독성 을 평가하기 위해 3-(4,5-dimethyl-2-thiazolyl)-2,5-diphenyl-2Htetrazolium bromide (MTT) assay를 수행하였으며 항산화와 항 주름 활성평가를 위해 ROS 생성능, hyaluronic acid 생성능, MMP-2, -9, TIMP-1,-2, TNF- $\alpha$ 의 발현을 각각 측정하였다. 베 르베린에 대한 자외선의 세포 독성은 CCD-986sk 섬유아세포를 이용하여 MTT 분석으로 측정되었고, 세포 독성이 $25 \mu \mathrm{g} / \mathrm{mL}$ 의 농도 미만에서 관찰되지 않았다. 또한 베르베린이 ROS 생산을 농도 의존적으로 감소시키고 히알루론산의 합성을 촉진한다는 것을 발견했다. 베르베린은 주름 형성과 관련된 MMP-2 및 MMP-9의 protein 단계 및 mRNA 발현을 감소시키고 TIMP-1 및 TIMP-2의 발현을 증가시켰다. 프로 pro-inflammatory cytokine 으로 알려진 TNF- $\alpha$ 에 대한 베르베린의 억제효능을 실 험한 결과, 농도의존적으로 $\mathrm{TNF}-\alpha$ 유전자를 억제하는 효과를 나타내었다. 이러한 결과를 통해 베르베린은 활성산소종의 억제 
와 TIMP-1과 -2 의 발현 조절에 의한 MMP-2,-9의 감소로 항산 화 및 항주름에 효과가 있는 화장품 소재로서의 가치를 가진다 고 사료된다.

Keywords 기질금속단백질분해효소·금속단백질분해효소 조직 억제제 · 베르베린 · 항노화 · 활성산소

감사의 글 본 연구는 환경부에서 지원하는 2015 년 환경산업선진화기술개 발사업(과제번호: 2015000150005)의 연구수행으로 진행되었으며, 이에 감사 드립니다.

\section{References}

An BJ, Lee JT, Lee CE, Kim JH, Son JH, Kwak JH, Lee JY, Park TS, Bae HJ, Jang MJ, Jo CH (2005) A Study on Physiological Activities of Coptidis Rhizoma and Application for Cosmetic Ingredients. Kor J Herbol 20: 83-92

Chae EY, Cho CS, Kim CJ (2009) The effect of Cationic Bovine Serum Albumin of Coptidis Rhizoma to Membranous Nephropathy Mouse Model. Kor J Herbol 24: 99-110

Choi EH, Lee TH (2006) Effects of Coptidis Rhizoma and Aconiti Lateralis Preparata Radix on the Change of Plasma Corticosterone Level and Rectal Temperature Induced by LPS. Kor J Herbol 21:77-85

Chung JH (2003) Photoaging in Asians. Photodermatol Photoimmunol Photomed 19: 109-121

Dübe B, Lüke HJ, Aumailley M, Prehm P (2001) Hyaluronan reduces migration and proliferation in $\mathrm{CHO}$ cells. Biochim Biophys Acta 1538: 283-289

Farage MA, Miller KW, Elsner P, Maibach HI (2008) Intrinsic and extrinsic factors in skin ageing: a review. Int J Cosmetic Sci 30: 87-95

Girolamo ND, Lloyd A, McCluskey P, Filipic M, Wakefield D (1997) Increased expression of matrix metalloproteinases in vivo in scleritis tissue and in vitro in cultured human scleral fibroblasts. Am J Pathol 150: 653-666

Gong YL, Xu GM, Huang WD, Chen LB (2000) Expression of matrix metalloproteinases and the tissue inhibitors of metalloproteinases and their local invasiveness and metastasis in chinese human pancreatic cancer. J Surg Oncol 73: 95-99

Greenlee KJ, Werb Z, Kheradmand F (2007) Matrix metalloproteinases in lung: multiple, multifarious and multifaceted. Physiol Rev 87: 69-98

Hwang ES, Lee DG, Park SH, Oh MS, Kim SY (2014) Coriander leaf extract exerts antioxidant activity and protects against UVB-induced photoaging of skin by regulation of procollagen type I and MMP-1 expression. J Med Food 17: 985-995

Hwang YP, Choi JH, Kim HG, Choi JM, Hwang SK, Chung YC, Jeong HG (2012) Cultivated ginseng suppresses ultraviolet B-induced collagenase activation via mitogen-activated protein kinases and nuclear factor NF$\kappa \mathrm{B} /$ activator protein-1-dependent signaling in human dermal fibroblasts. Nutr Res 32: 428-438

Iwata H, Kobayashi S, Iwase H, Masaoka A, Fujimoto N, Okada Y (1996) Production of matrix metalloproteinases and tissue inhibitors of metalloproteinases in human breast carcinomas. Jpn J Cancer Res 87: $602-611$

Jeong JY, Kim MY (2006) Color atlas \& overview of skin care; aging of skin, mdworld, Seoul, pp 25-30

Johnson MD, Kim HR, Chesler L, Tsao-Wu G, Bouck N, Polverini PJ (1994) Inhibition of angiogenesis by tissue inhibitor of metalloproteinase. J Cell Physiol 160: 194-202

Kim JO, Lee CW, Kim EK, Lee SJ, Park NH, Kim HS, Kim HK, Char KH,
Jang YP, Kim JW (2011) Inhibition effect of Gynura procumbens extract on UV-B-induced matrix-metalloproteinase expression in human dermal fibroblasts. J Ethnopharmacol 137: 427-433

Kim KT, Kim YH, Kim JG, Han CS, Park SH, Lee BY, Kim KH (2007) Preparation of oligo hyaluronic acid by hydrolysis and its application as a cosmetic ingredient. J Soc Cosmet Sci Kor 33: 189-196

Lambert E, Dasse E, Haye B, Petitfrere E (2004) TIMPs as multifacial proteins. Crit Rev Oncol Hematol 49: 187-198

Li B, Liu HR, Pan YQ, Jiang QS, Shang JC, Wan XH, He BC, Yang JQ, Zhou QX (2006) Protective effects of total alkaloids from rhizoma Coptis chinensis on alcohol-induced gastric lesion in rats. Zhongguo Zhong Yao Za Zhi 31: 51-45

Meinhard W, Iiana TB, Lale N, Wenjian M, Lars AS, Ziba RW, Jutta S, Karin SK (2001) Solar UV irradiation and dermal photoaging. J Photochem Photobiol B 63: 41-51

Moon HJ, Lee SR, Shim SN, Jeong SH, Stonik VA, Rasskazov VA, Zvyagintseva T, Lee YH (2008) Fucoidan inhibits UVB-induced MMP-1 expression in human skin fibroblasts. Biol Pharm Bull 31: 284-289

Muller D, Wolf C, Abecassis J, Millon R (1993) Increased stromelysin 3 gene expression is associated with local invasiveness in head and neck squamous cell carcinomas. Cancer Res 53: 165-169

Park SH, Lee KH, Han CS, Kim KH, Kim YH (2010) Inhibitory effects of Carex humilis extract on elastase activity and matrix metalloproteinase-1 expression. J Soc Cosmet Sci Kor 36: 129-136

Pentland AP, Shapiro SD, Welgus HG (1995) Agonistinduced expression of tissue inhibitor of metalloproteinases and metalloproteinases by human macrophages is regulated by endogenous prostaglandin E2 synthesis. J Invest Dermatol 104: 52-57

Ries C (2014) Cytokine functions of TIMP-1. Cell Mol Life Sci 71: 659-672

Sanceau J, Boyd DD, Seiki M, Bauvois B (2002) Interferons inhibit tumor necrosis factor-alpha-mediated matrix metalloproteinase- 9 activation via interferon regulatory factor-1 binding competition with NF-kappa B. J Biol Chem 277: 35766-35775

Seo KY, Im CY, Lee JH (2004) Increased Tear TNF-alpha and MMP-9 in Patients with Necrotizing Scleritis after Pterygium Excision. J Korean Ophthalmol Soc 45: 720-724

Shindo Y, Witt E, Packer L (1993) Antioxidants defense mechanisms in murine epidermis and dermis and their responses to ultraviolet light. J Invest Dermatol 100: 260-265

Song HJ, Jin MH Lee SH (2013) Effect of ferulic acid isolated from Cnidium officinale on the synthesis of hyaluronic acid. J Soc Cosmet Sci Korea 39: 281-288

Terada T, Okada Y, Nakanuma Y (1996) Expression of immunoreactive matrix metalloproteinases and tissue inhibitors of matrix metalloproteinases in human normal livers and primary liver tumors. J Hepatol 23: 1341-1344

Uzui H, Harpf A, Liu M, Doherty TM, Shukla A, Chai N (2002) Increased expression of membrane type 3-matrix metalloproteinase in human atherosclerotic plaque: role of activated macrophages and inflammatory cytokines. Circulation 106: 3024-3030

Wong TT, Sethi C, Daniels JT, Murphy G, Khaw PT (2002) Matrix metalloproteinases in disease and repair processes in the anterior segment. Surv Ophthalmol 47: 239-256

Yaar M1, Gilchrest BA (2007) Photoageing: mechanism, prevention and therapy. Br J Dermatol 157: 874-887

Yamahara J (1976) Central depressive action of Coptidis rhizoma and its constituents. Nihon Yakurigaku Zasshi 72: 899-908

Yoo HG (1996) Effect of Rhizoma coptidis and Centella asiatica extracts on human gingival fibroblasts. J Periodontal Implant Sci 26: 681-688

Zi-Min Y, Yue C, Hui G, Jia L, Gui-Rong C, Wang J (2017) Comparative Pharmacokinetic Profiles of Three Protoberberine-type Alkaloids from Raw and Bile-processed Rhizoma coptidis in Heat Syndrome Rats. Pharmacogn Mag 13: 51-57 